\title{
Accelerated Aging Test to Determine the Vigor of Mungbean Seeds
}

\author{
Luciana Maria da Silva ${ }^{1}$, Anderson Dias Vaz de Souza ${ }^{1}$, Rogério Lámim Silva Junior ${ }^{1}$, Natália Arruda ${ }^{1}$, \\ Nei Peixoto ${ }^{1} \&$ Katiane Santiago Silva Benett ${ }^{1}$ \\ ${ }^{1}$ Department of Agronomy, State University of Goiás, Câmpus Ipameri, Ipameri, Goias, Brazil \\ Correspondence: Natália Arruda, Department of Agronomy, State University of Goiás, Campus Ipameri, Ipameri, \\ Goias, Brazil. Tel: 55-643-491-1556. E-mail: nathy.a@hotmail.com
}

$\begin{array}{ll}\text { Received: February 19, } 2019 & \text { Accepted: March 21, } 2019 \quad \text { Online Published: May 31, } 2019 \\ \text { doi:10.5539/jas.v11n7p42 } & \text { URL: https://doi.org/10.5539/jas.v11n7p42 }\end{array}$

\begin{abstract}
The use of good quality seeds is fundamental for proper establishment of a crop. In this way, for more precise determination of seed quality, vigor tests are performed in addition to the germination test. These tests enable the selection of the best lots for commercialization and planting. This study evaluates the effects of temperature and exposure times of the accelerated aging test for vigor classification of mungbean seed lots. Seeds of the mungbean cultivar Esmeralda were used, being obtained from four cultivated plots at the State University of Goiás (UEG), Ipameri Câmpus, in the 2013, 2015, 2016, and 2017 harvests. The lots were initially characterized using germination and vigor tests (first germination count, germination rate index, seedling length, and seedling fresh and dry weight). The accelerated aging test was conducted with a completely randomized experimental design, in a $2 \times 4$ factorial arrangement consisting of two temperatures $\left(40\right.$ and $\left.42{ }^{\circ} \mathrm{C}\right)$ and four times $(24,48,72$, and 96 hours), with four replicates of 50 seeds per lot. The lots showed significant differences in the germination test, first germination count, germination rate index, and seedling length. The accelerated aging test was efficient in classifying lots. Lot 3 obtained the best results, while lot 1 obtained the lowest ones. The combination of $42{ }^{\circ} \mathrm{C}$ temperature and $72 \mathrm{~h}$ of seed exposure to the accelerated aging test is the best to classify mungbean seed lots.
\end{abstract}

Keywords: Vigna radiata L., temperature, exposure time, seed quality

\section{Introduction}

Mungbean (Vigna radiata L.) belongs to the family Fabaceae, being one of the most cultivated legumes during summer in tropical and subtropical climates (Tang et al., 2014a). The species is native to India, and was domesticated about 4,500 years ago. Currently, it is cultivated mainly in regions of Asia, India, China, and Pakistan. Regions such as Africa, USA, and Australia also cultivate this species, but on a smaller scale (Smýkal et al., 2015).

In fact, Asia accounts for $90 \%$ of the world production of mungbean, in which India represents about $50 \%$ of the total production. Currently, China is the largest exporter of seeds of this bean (Misiak et al., 2017). In Brazil, mungbean is cultivated on a small scale, and is little studied. Nevertheless, the species has been gaining market share, especially for the production of bean sprouts (moyashi) at different times of the year, highlighting the region of Minas Gerais (Vieira et al., 2011).

Mungbean is considered a good source of protein, carbohydrate, and minerals, besides being rich in vitamins, particularly thiamine, riboflavin, and niacin (Luo et al., 2016; Lim, 2012). It can be consumed by animals and humans in the form of pods, green seeds, dried seeds, or shoots (Kahraman et al., 2014). The seeds are also used in the pharmaceutical and cosmetic industries (Shaheen et al., 2012).

The use of good quality seeds is fundamental for proper establishment of a crop. In this way, for more precise determination of seed quality, vigor tests are performed in addition to the germination test. These tests enable the selection of the best lots for commercialization and planting (Araujo et al., 2011).

The seed vigor test is determined under unfavorable conditions by measuring the reduction of the biochemical or physiological function of seeds. It should be fast, economical, reproducible, and the results should be similar to those observed in the field. A vigor test with the desired characteristics is the accelerated aging test (Bertolin et al., 2011). 
The accelerated aging test is based on simulations between different environmental factors, such as high relative humidity and high temperatures. Thus, the test consists of situations where the seeds are subjected to high temperature and relative humidity during a certain period, and responses are observed by standard germination test (Guedes et al., 2013). This test allows to detect differences in the physiological quality of seed lots with similar germinative capacity, which may present different behaviors due to long storage times and the various conditions of field cultivation (Flávio \& Paula, 2010; Marcos Filho, 2015).

When working with accelerated aging test parameters to determine the vigor of bean seeds, Bertolin et al. (2011) observed that bean seeds with good quality (germination) present alterations in the accelerated aging test; the authors obtained satisfactory results when using the temperature of $43{ }^{\circ} \mathrm{C}$ for $24 \mathrm{~h}$. Guiscem et al. (2010), evaluating both the cold test and the accelerated aging test in the determination of asparagus bean seed vigor, observed positive results when using the temperature of $43{ }^{\circ} \mathrm{C}$ for $48 \mathrm{~h}$.

Therefore, in view of the promising market for mungbean cultivation and the need for further studies on both the vigor and accelerated aging tests for this crop, the present study is of great importance for guidance and consequent success in green mungbean cultivation. This study evaluates the effects of temperature and exposure times of the accelerated aging test for vigor classification of mungbean (Vigna radiata L.) seed lots.

\section{Materials and Methods}

The experiment was carried out in the Seed Laboratory of the State University of Goiás, Ipameri Campus, located in Ipameri city, Goiás State. Seeds of mungbean cultivar Esmeralda, made available by the Agricultural Research Company of Minas Gerais (EPAMIG), were obtained from four plots cultivated at the institution, in the 2013, 2015, 2016, and 2017 harvests.

Before the installation of the experiment, the seeds were disinfected with $1 \%$ hypochlorite solution. Subsequently, each seed lot was characterized according to the recommendations of the Rules for Seed Analysis (MAPA, 2009). The following were evaluated:

Seed moisture content ( $\%$ w.b.): determined in an oven at $105^{\circ} \mathrm{C}$ for 24 hours, as specified by the Rules for Seed Analysis (MAPA, 2009). Results were expressed as percentage moisture content in wet basis (\% w.b.).

Germination test (\%): conducted with four replicates of 50 seeds per lot, using germitest paper towels moistened with distilled water at a ratio of 2.5 times the weight of the dry paper. The towels were packed in plastic bags and taken to germination chambers at $25{ }^{\circ} \mathrm{C}$. The evaluation of normal seedlings was performed on the seventh day after the test installation. Results were expressed as percentage of normal seedlings (\%) (MAPA, 2009).

First germination count (\%): concomitant to the germination test, but the evaluation of normal seedlings was performed on the fifth day after the test installation. Results were expressed as percentage of normal seedlings.

Germination rate: concomitant to the germination test, but the seeds were evaluated every day until the last evaluation, on the seventh day after the germination test. Upon completion of daily evaluations, the germination rate index was calculated according to Maguire (1962), the result being obtained by means of the formula: IVE = $\mathrm{E} 1 / \mathrm{N} 1+\mathrm{E} 2 / \mathrm{N} 2+\ldots+\mathrm{En} / \mathrm{Nn}$, where, E1, E2, and En—number of normal seedlings computed in the first, second, and until the last count; $\mathrm{N} 1, \mathrm{~N} 2$, and $\mathrm{Nn}$-number of days after the test installation.

Seedling length $(\mathrm{cm})$ : carried out with four replicates of 25 seeds per lot, using germitest paper towels moistened with distilled water at a rate of 2.5 times the weight of the dry paper. Seeds were distributed in two longitudinal straight rows. The towels were packed in plastic bags and taken to germination chambers at $25^{\circ} \mathrm{C}$. Seedling length was obtained with the aid of a graduated ruler on the fifth day after the test installation.

Fresh and dry weight of normal seedlings ( $g$ ): after determining the length, seedlings were weighed on a precision scale to determine the fresh weight. For dry weight determination, the seedlings were placed in paper bags and dried in a forced-air oven at $65^{\circ} \mathrm{C}$ for $72 \mathrm{~h}$. Results were expressed in grams.

After the initial characterization of the lots, the accelerated aging test was conducted with a completely randomized experimental design, in a $2 \times 4$ factorial arrangement consisting of two temperatures $\left(40\right.$ and $\left.42{ }^{\circ} \mathrm{C}\right)$ and four times (24, 48, 72, and 96 hours), with four replicates of 50 seeds per lot.

The seeds were packed in transparent "gerbox" $(11 \times 11 \times 3.5 \mathrm{~cm})$, being placed in a single layer on a screen attached to the inside of boxes, containing $40 \mathrm{~mL}$ of distilled water in the bottom, as described by Marcos Filho (1999b). The boxes were capped and taken to a BOD chamber, being maintained at the temperatures and times stipulated above. 
After each aging period, new tests on germination and seed moisture content were performed, following the methodology described previously. Results were expressed as percentage of normal seedlings (\%) and percentage moisture content in wet basis (\% w.b.).

Data were submitted to analysis of variance ( $\mathrm{F}$ test), and the means were compared by the Tukey test $(\mathrm{p} \leq 0.05)$. Statistical analyses were processed using the SISVAR program (Ferreira, 2011).

\section{Results and Discussion}

The mean values of the germination test were between 90 and $99 \%$ normal seedlings (Table 1). These values meet the standards for commercialization of Vigna spp. seeds, being within the stipulated limit $(\geq 80 \%$ germination) (Brazil, 2013). The first germination count showed a significant difference between the lots, in which lots 2 and 3 had higher values than lots 1 and 4 . The germination rate index also showed a significant difference between the lots, classifying lot 4 as superior and lot 3 as inferior. The first germination count test is used because it is easy to perform, in addition to indicating the approximate physiological potential of each seed lot, which helps to classify seed lots (Lopes et al., 2010).

Table 1. Mean values of mungbean moisture content (MC), germination (GERM), first germination count (FGC), germination rate index (GRI), seedling length (SL), seedling fresh weight (SFW), and seedling dry weight (SDW). Ipameri-GO, 2018

\begin{tabular}{llllllll}
\hline Lots & MC & GERM & FGC & GRI & SL & SFW & SDW \\
\hline & $-10.25 \mathrm{a}^{1}$ & $90 \mathrm{~b}$ & $90 \mathrm{~b}$ & $40.25 \mathrm{ab}$ & $17.00 \mathrm{~b}$ & $12.50 \mathrm{a}$ & $10.00 \mathrm{a}$ \\
2 & $11.00 \mathrm{a}$ & $98 \mathrm{a}$ & $98 \mathrm{a}$ & $37.50 \mathrm{~b}$ & $22.00 \mathrm{ab}$ & $10.00 \mathrm{a}$ & $9.75 \mathrm{a}$ \\
3 & $10.50 \mathrm{a}$ & $99 \mathrm{a}$ & $99 \mathrm{a}$ & $36.50 \mathrm{~b}$ & $19.25 \mathrm{ab}$ & $11.50 \mathrm{a}$ & $10.00 \mathrm{a}$ \\
4 & $10.25 \mathrm{a}$ & $91 \mathrm{~b}$ & $91 \mathrm{~b}$ & $42.50 \mathrm{a}$ & $23.75 \mathrm{a}$ & $12.25 \mathrm{a}$ & $10.00 \mathrm{a}$ \\
\hline CV $(\%)$ & 7.01 & 2.77 & 2.77 & 5.50 & 15.13 & 10.81 & 2.52 \\
\hline
\end{tabular}

Note. Means followed by the same letter in the column do not differ by Tukey test at $5 \%$ probability.

For seedling length, the means also presented significant difference, where lot 4 was shown to be superior, but similar to lots 2 and 3 , while lot 1 presented the lowest values. The results for seedling fresh and dry weight did not differ statistically between the lots (Table 1).

According to the results of the germination and vigor tests, lot 3 presented the highest averages and lot 1 had the lowest values. Based on seedling performance, vigor tests are taken as physiological tests, determining specific physiological activities as a function of seed vigor (Santos et al., 2017).

These results highlighted the need to perform other tests before classifying the lots for their physiological potential (Tunes et al., 2012). Each test provides complementary information regarding the storage time and its potential to establish a larger plant stand under wide variation of environmental conditions (Marcos Filho et al., 2009).

Table 2 shows the moisture content values for each seed lot after the seeds were subjected to the accelerated aging test at 40 and $42{ }^{\circ} \mathrm{C}$ for four times. After applying the accelerated aging test, moisture content values varied from 13.46 to $16.06 \%$ for lot 1 , from 15.25 to $19.43 \%$ for lot 2 , from 10.98 to $15.16 \%$ for lot 3 , and from 14.61 to $17.49 \%$ for lot 4 , between the lowest and the highest exposure time of the accelerated aging test, respectively.

These values agree with Marcos Filho (1999b) and are similar to those observed by Bertolini et al. (2011) when determining vigor in bean seeds through the accelerated aging test. This demonstrates the uniformity of test conditions. Seed water content increased as a function of increasing temperatures and exposure times.

Regarding the accelerated aging test, mungbean lots presented significant difference when exposed to different temperatures and exposure times (Table 3). These results are similar to those observed by Guiscem et al. (2010). When determining vigor in asparagus bean seeds by means of the cold test and the accelerated aging test, these authors observed that the combination of $43{ }^{\circ} \mathrm{C} / 48 \mathrm{~h}$ was the most adequate to evaluate the physiological potential of asparagus bean cultivars. 
When evaluating temperatures regardless of the exposure time, we observed a significant difference. At $40{ }^{\circ} \mathrm{C}$, the lots showed a higher percentage of normal seedlings, whereas the temperature of $42{ }^{\circ} \mathrm{C}$ decreased the percentage of normal seedlings.

Table 2. Moisture content of mungbean seeds after different exposure times (24, 48, 72, and 96 hours) and temperatures $\left(40\right.$ and $\left.42{ }^{\circ} \mathrm{C}\right)$ of the accelerated aging test

\begin{tabular}{|c|c|c|c|c|}
\hline \multirow{2}{*}{ Temperature/Times } & \multicolumn{4}{|c|}{ Lots } \\
\hline & 1 & 2 & 3 & 4 \\
\hline \multicolumn{5}{|l|}{$40^{\circ} \mathrm{C}$} \\
\hline $24 \mathrm{~h}$ & 11.43 & 10.06 & 9.34 & 9.93 \\
\hline $48 \mathrm{~h}$ & 13.83 & 13.88 & 6.25 & 11.94 \\
\hline $72 \mathrm{~h}$ & 14.02 & 14.42 & 7.44 & 12.31 \\
\hline $96 \mathrm{~h}$ & 16.97 & 16.07 & 15.51 & 16.10 \\
\hline \multicolumn{5}{|l|}{$42^{\circ} \mathrm{C}$} \\
\hline $24 \mathrm{~h}$ & 13.46 & 15.25 & 10.98 & 14.61 \\
\hline $48 \mathrm{~h}$ & 14.36 & 18.13 & 10.91 & 14.97 \\
\hline $72 \mathrm{~h}$ & 15.24 & 19.06 & 11.61 & 17.14 \\
\hline $96 \mathrm{~h}$ & 16.06 & 19.43 & 15.16 & 17.49 \\
\hline
\end{tabular}

In the association between temperature and exposure time, lots 1 and 2 did not show significant differences in the different exposure times at $40{ }^{\circ} \mathrm{C}$. For lots 3 and 4, in turn, the germination percentage decreased after $72 \mathrm{~h}$ of exposure to the test. Moreover, lot 3 was shown to be the least sensitive to the different seed exposure times. This fact may be related to seed vigor, as previously determined, classifying lot 3 as the most vigorous.

At $42{ }^{\circ} \mathrm{C}$, lots 1 and 4 did not show significant differences between the exposure times, but lots 2 and 3 presented a decrease in the percentage of normal seedlings. For the latter, the exposure time of 96 hours accounted for the lowest mean germination values, of $48 \%$ and $63 \%$, respectively.

Table 3. Results of the accelerated aging test for mungbean seeds under two temperatures and four exposure times

\begin{tabular}{|c|c|c|c|c|}
\hline \multirow{2}{*}{ Temperature/Times } & \multicolumn{4}{|c|}{ Lots } \\
\hline & 1 & 2 & 3 & 4 \\
\hline \multicolumn{5}{|l|}{$40^{\circ} \mathrm{C}$} \\
\hline $24 \mathrm{~h}$ & $82 \mathrm{Aa}^{1}$ & $93 \mathrm{Aa}$ & $94 \mathrm{Aa}$ & $93 \mathrm{Aa}$ \\
\hline $48 \mathrm{~h}$ & $71 \mathrm{Aa}$ & $93 \mathrm{Aa}$ & $91 \mathrm{Aa}$ & $90 \mathrm{Aab}$ \\
\hline $72 \mathrm{~h}$ & $64 \mathrm{Aa}$ & $81 \mathrm{Aa}$ & $82 \mathrm{Ab}$ & $77 \mathrm{Ab}$ \\
\hline $96 \mathrm{~h}$ & $67 \mathrm{Aa}$ & $88 \mathrm{Aa}$ & $95 \mathrm{Aa}$ & $86 \mathrm{Aab}$ \\
\hline \multicolumn{5}{|l|}{$42^{\circ} \mathrm{C}$} \\
\hline $24 \mathrm{~h}$ & $48 \mathrm{Ba}$ & $78 \mathrm{Bab}$ & $82 \mathrm{Bb}$ & $67 \mathrm{Ba}$ \\
\hline $48 \mathrm{~h}$ & $57 \mathrm{Ba}$ & $84 \mathrm{Ba}$ & $90 \mathrm{Ba}$ & $79 \mathrm{Ba}$ \\
\hline $72 \mathrm{~h}$ & $55 \mathrm{Ba}$ & $66 \mathrm{Bb}$ & $82 \mathrm{Bb}$ & $73 \mathrm{Ba}$ \\
\hline $96 \mathrm{~h}$ & $44 \mathrm{Ba}$ & $48 \mathrm{Bc}$ & $63 \mathrm{Bc}$ & $67 \mathrm{Ba}$ \\
\hline $\mathrm{CV}(\%)$ & 18.63 & 9.45 & 3.78 & 8.81 \\
\hline
\end{tabular}

Note. Means followed by the same letter in the column do not differ by Tukey test at $5 \%$ probability.

When evaluating the behavior of each lot at the different temperatures and exposure times of the accelerated aging test, lot 3 was shown to be less sensitive than the other lots at $42{ }^{\circ} \mathrm{C}$ temperature and $72 \mathrm{~h}$ exposure time, with $82 \%$ of normal seedlings. Lot 1 showed the worst performance, with $55 \%$ of normal seedlings. This setting of temperature and time is recommended for grading of mungbean seed lots.

Corroborating with Bertolin et al. (2011), with the application of the accelerated aging test, there was decreased germination and increased deterioration of mungbean seeds as a function of increasing exposure time within each temperature. Regarding the behavior of each lot, some materials were shown to be more resistant to the 
adverse conditions imposed by the test, which suggests the need for studies with different temperatures and exposure times. Notwithstanding, this characteristic can be considered favorable when mungbean is cultivated under conditions of high temperatures and high humidity.

\section{Conclusion}

When evaluating the vigor of mungbean seed lots, it is recommended to subject the seeds to the accelerated aging test at the temperature of $42{ }^{\circ} \mathrm{C}$ and exposure time of 72 hours.

\section{Acknowledgements}

To the State University of Goiás (Universidade Estadual de Goiás-UEG), Câmpus Ipameri, to the Strito Senso Plant Production Post-Graduation Program (PPGPV) and to the Seed Laboratory (LASEM UEG-Câmpus Ipameri) for the support in the conduction of the project.

\section{References}

Araujo, R. F., Zonta, J. B., Araujo, E. F., Heberle, E., \& Zonta, F. M. G. (2011). Teste de condutividade elétrica para sementes de feijão-mungo-verde. Revista Brasileira de Sementes, 33(1), 123-130. https://doi.org/ $10.1590 / \mathrm{S} 0101-31222011000100014$

Bertolin, D. C., Sá, M. E. de, \& Moreira, E. R. (2011). Parâmetro do teste de envelhecimento acelerado para determinação do vigor de sementes de feijão. Revista Brasileira de Sementes, 33(1), 104-112. https://doi.org/10.1590/S0101-31222011000100012

Ferreira, D. F. (2011). Sisvar: A computer statistical analysis system. Ciência e Agrotecnologia, 35(6), 1039-1042.

Flávio, J. J. P. \& Paula, R. C. de (2010). Testes de envelhecimento acelerado e de contutividade elétrica em sementes de Dictyoloma vandellianum A. Juss. Scientia Forestalis, 38(87), 391-399.

Guedes, R. S., Alves, E. U., \& Oliveira, L. S. B. (2013). Teste de envelhecimento acelerado em sementes de Chorisia glaziovii (Kuntze) (Malvaceae). Bioscience Journal, 29(2), 378-385.

Guiscem, J. M., Farias, A. De. S., Figueiredo, R. T. De, Chaves, A. M. Da. S., Figueiredo, B. T. De, Pereira, C. F., ... Martins, M. R. (2010). Teste de frio e envelhecimento acelerado na avaliação de vigor de sementes de feijão-frade. Revista de Ciências Agrárias, 33(2), 182-191.

Kahraman, A., Adali, M., Onder, M., \& Koc, N. (2014). Mung Bean [Vigna radiata (L.) Wilczek] as Human Food. International Journal of Agriculture and Economic Development, 2(2), 9.

Lim, T. K. (2012). Vigna radiata. Edible Medicinal and Non-Medicinal Plants (pp. 951-959). Dordrecht. https://doi.org/10.1007/978-94-007-1764-0_100

Lopes, M. M., Sader, R., Paiva, A. S., Ernandes, A. C. (2010). Teste de envelhecimento acelerado em sementes de quiabo. Bioscience Journal, 26(4), 491-501.

Luo, J., Cai, W., Tong, W., \& Xu, B. (2016). Phytochemical distribution in hull and cotyledon of adzuki bean (Vigna angularis L.) and mung bean (Vigna radiata L.), and their contribution to antioxidant, antiinflammatory and anti-diabetic activities. Food Chemistry, 201, 350-360. https://doi.org/10.1016/j. foodchem.2016.01.101

Maguire, J. D. (1962). Speed of germination-aid selection and evaluation for seedling emergence and vigor. Crop Science, 2(1), 176-177. https://doi.org/10.2135/cropsci1962.0011183X000200020033x

MAPA (Ministério da Agricultura, Pecuária e Abastecimento). (2009). Regras para análise de sementes (p. 395). Brasília.

MAPA (Ministério da Agricultura, Pecuária e Abastecimento). (2013). Instrução Normativa n. 45, de 17 de setembro de 2013, Estabelece os padrões de identidade e qualidade para a produção e a comercialização de sementes. Diário Oficial União, Poder Executivo, Brasília, DF, Anexo XII, 20 Setembro.

Marcos Filho, J. (1999a). Testes de vigor: Importância e utilização. In F. C. Krzyzanowski, R. D. Vieira, \& J. B. França Neto (Eds.), Associação Brasileira de Tecnologia de Sementes (pp. 1-21). Londrina: Vigor de Sementes: Conceitos e Testes Londrina.

Marcos Filho, J. (1999b). Testes de envelhecimento acelerado. In F. C. Krzyzanowski, R. D. Vieira, \& J. B. França Neto (Eds.), Associação Brasileira de Tecnologia de Sementes (pp. 1-24). Londrina: Vigor de sementes: conceitos e testes. Londrina. 
Marcos Filho, J. (2015). Fisiologia de sementes de plantas cultivadas (p. 659). Associação Brasileira de Tecnologia de Sementes.

Marcos Filho, J., Kikuti, A. L. P., \& Lima, L. B. D. (2009). Métodos para avaliação do vigor de sementes de soja, incluindo a análise computadorizada de imagens. Revista Brasileira de Sementes, 31(1), $102-112$. https://doi.org/10.1590/S0101-31222009000100012

Misiak, K., Górna, B., Król, E., \& Holubowicz, R. (2017). Yield and Quality of Mung Bean (Vigna radiate (L.) R. Wilczek) Seeds Produced in Poland. Bulletin UASVM Horticulture, 74(2), 149-155.

Santos, A. S. Dos, Souza, E. M. De, Féboli, A., \& Nogueira, D. C. (2017). Testes de vigor em sementes de três cultivares de soja. Revista Conexão Eletrônica, 14(1), 674-685.

Shaheen, S., Harun, N., Hussain, R. A., Ramzan, S., Khalid, Z., Ahmad, M., \& Zafar, M. (2012). Comparative nutritional analysis between Vigna radiata and Vigna mungo of Pakistan. African Journal of Biotechnology, Ebène, 11(25), 6694-6702. https://doi.org/10.5897/AJB11.3496

Smýkal, P., Coyne, C. J., Ambrose, M. J., Maxted, N., Schaefer, H., Blair, M. W., ... Varshney, R. K. (2015). Legume Crops Phylogeny and Genetic Diversity for Science and Breeding. Critical Reviews in Plant Sciences, 34(1-3), 43-104. https://doi.org/10.1080/07352689.2014.897904

Tang, D., Dong, Y., Guo, N., Li, L., \& Ren, H. (2014). Metabolomic analysis of the polyphenols in germinating mung beans (Vigna radiata) seeds and sprouts. Journal of the Science of Food and Agriculture, 94(8), 1639-1647. https://doi.org/10.1002/jsfa.6471

Tunes, L. M. De, Tavares, L. C., \& Barros, A. C. S. A. (2012). Envelhecimento acelerado como teste de vigor para sementes de arroz. Revista de Ciências Agrárias, 35(1), 120-127.

Vieira, R. F., De Paula Junior, R. J., Jacob, L. L., Silva Lehner, M. Da, \& Santos, J. Dos. (2011). Desempenho de genótipos de feijão-mungo-verde semeados no inverno na Zona da Mata de Minas Gerais. Revista Ceres, 58(3), 402-405. https://doi.org/10.1590/S0034-737X2011000300022

\section{Copyrights}

Copyright for this article is retained by the author(s), with first publication rights granted to the journal.

This is an open-access article distributed under the terms and conditions of the Creative Commons Attribution license (http://creativecommons.org/licenses/by/4.0/). 